\title{
Lost in Administration : (Re)Producing Precarious Citizenship for Young University-Educated Intra-EU Migrants in Brussels
}

\section{Simola, Anna}

2018-06-01

Simola , A 2018 , ' Lost in Administration : (Re)Producing Precarious Citizenship for Young University-Educated Intra-EU Migrants in Brussels ', Work, Employment and Society, vol. 32 , no. 3 , pp. 458-474 . https://doi.org/10.1177/0950017018755653

http://hdl.handle.net/10138/310224

https://doi.org/10.1177/0950017018755653

unspecified

acceptedVersion

Downloaded from Helda, University of Helsinki institutional repository.

This is an electronic reprint of the original article.

This reprint may differ from the original in pagination and typographic detail.

Please cite the original version. 


\title{
Lost in administration - (re)producing precarious citizenship for young university-educated intra-EU migrants in Brussels
}

\author{
Anna Simola \\ University of Helsinki, Finland
}

\begin{abstract}
:
The mounting backlash against intra-EU migration in various EU countries has triggered national policies seeking to restrict EU citizens' social rights and freedom of movement. Building on and expanding Noora Lori's (2017) work around this concept, the article examines intra-EU migrants' increasingly unsettled legal statuses as potentially precarious citizenship. Focussing on the experiences of young university-educated intra-EU migrants in Brussels, the article claims that, in the absence of straightforward EU legislation and explicit government policies, administrative actors use their discretion to draw indeterminate boundaries enforcing conditionality and temporariness of status for EU citizens in precarious work arrangements, therefore often increasing the pressure on them to take further precarious jobs. The article argues that, under the conditions of precarious employment, not even migrants with privileged access to citizenship rights are protected from processes of boundary enforcement that institutionalise the ambiguity of statuses and produce precarious citizenship.
\end{abstract}

Keywords: administrative discretion, boundary enforcement, Brussels, conditionality, EU citizenship, intra-EU migrants, legal status, precarious citizenship, precarious employment, temporariness 


\section{Corresponding author:}

Anna Simola, Department of Social Research, University of Helsinki, PL 54, 00014, University of Helsinki, Finland. Email: anna.simola@helsinki.fi

\section{Introduction}

'I thought that there was freedom of movement. I thought - and that's what everyone here thinks - that you can allow yourself all the time you wish to find a job. Well, no, it's not like that. Because it's those famous three months, 90 days or you have to leave.' (Carlos, a 29 year old Spaniard with two Masters degrees, interviewed in Brussels in June 2014) ${ }^{1}$

Over recent decades, European and national authorities have encouraged young Europeans towards educational and labour mobility within the European Union (EU) (European Commission, 2010a). However, a growing gap has emerged between the EU political discourse promoting mobility and the realities faced by EU citizens making use of their right to free movement. The mounting backlash against intra-EU migration in various EU member states has triggered national policies that seek to restrict EU citizens' freedom of movement and to reinforce a work-related conditionality approach in determining their rights (Shutes, 2016). The British vote to leave the EU is of course the most striking manifestation of the growing popular pressure to re-establish 'protective' control over national borders, labour markets and welfare systems (O'Reilly et al., 2016: 808-812). However, even before the Brexit referendum, the UK, together with countries such as the Netherlands, Germany and Belgium, has found unique ways to limit EU citizens' access to rights. These restrictions are assumed to have a direct impact on the employment and wider social precariousness of intra-EU migrants (Alberti, 2016; O'Brien, 2016; Shutes and Walker, 2018). While scholars in the fields of migration, EU law and policy and social policy have drawn attention to the evolving free movement policy framework (e.g. Anderson, 2015; Gsir et al., 2016; O’Brien, 
2016; Lillie and Simola, 2016), the experiences of intra-EU migrants impacted by the local implementation of these policies have so far, with very few exceptions (Mescoli and Lafleur, 2016; Shutes and Walker, 2018), not been studied.

Aiming to fill this gap, this article explores these changes examining the experiences of young university-educated intra-EU migrants who have faced disadvantage in the labour market in their 'host country' and have consequently ended up living under insecure and economically vulnerable conditions. Their experiences reflect the increasing exposure of young qualified Europeans, both migrant and non-migrant, to the risk of unemployment and precarious types of employment, characterised by temporal and non-standard contractual relationships, insecurity, low or no pay, lack of control over work process and conditions of work and limited access to social and labour protection (Chung et al., 2012; Rodgers, 1989; Samek Lodovici and Semenza, 2012).

The study is conducted in Brussels, which can arguably be seen as a hub of European free movement. Both symbolically and substantively Brussels constitutes a key destination for European-minded young professionals who typically move there in search of international job opportunities (Favell, 2008). However, it is a highly competitive environment where young workers face considerable challenges (EURES, 2016). In addition, in recent years Belgium has used social policies as a means to regulate intra-EU migration and the access of migrants to social entitlements in a number of ways, inter alia, by expelling EU citizens who are considered economically unproductive and hence undesirable (Gsir et al., 2016).

This article examines the increasingly unsettled legal statuses of intra-EU migrants as potentially precarious citizenship - an emerging concept that Noora Lori (2017) applies to refer to people who, for a range of reasons, are unable to gain access to secure and permanent citizenship status. She argues that ambiguous and temporal legal statuses are proliferating across the globe because they represent a strategic government response to avoid resolving dilemmas of citizenship inherent to the conditions of statelessness, 'illegality' and an array of temporary statuses. This 
article expands Lori's discussion, with its starting point in Middle East studies, by applying the concept of precarious citizenship in a notably different context to capture the experiences of young intra-EU migrants. The argument is that under the conditions of precarious employment, not even migrants who, in global terms, have privileged access to formal citizenship rights, are protected from processes of boundary enforcement that institutionalise the ambiguity of statuses and produce precarious citizenship (cf. Lori, 2017).

The article adopts a multi-dimensional approach in order to analyse the vulnerabilities associated with insecure legal statuses for EU citizens in their interconnections with precarious employment (cf. Anderson, 2010; cf. Goldring and Landolt, 2011; Vosko 2006: 4). The argument is thus developed by examining the complex intersections of the increasing precarisation of employment relations, the changing social and legal norms regulating the free movement of EU citizens and the local bureaucratic implementation of these norms - a dynamic that is poorly understood in the sociology of work. The article argues that in the absence of straightforward EU legislation and explicit government policies at a national level, the administrative actors use their discretion to draw and enforce indeterminate boundaries making legal statuses and the associated rights increasingly conditional, temporary and insecure for intra-EU migrants in precarious work arrangements. The findings point to a consequential role for administrations in producing precarious citizenship. Moreover, while the reasons for which young intra-EU migrants enter precarious employment are intricate, the empirical evidence presented in this article indicates that the institutionally enforced uncertainty and temporariness of legal statuses and the associated lack of social rights often increase the pressure on them to take further precarious jobs, thus closing a vicious circle.

Intersections of disadvantage for young intra-EU migrants in the institutionally embedded labour markets 
Understanding the complex factors driving young university-educated intra-EU migrants into precarious employment requires taking into account migration patterns and processes as well as the changes in the social, political and institutional frameworks in which the labour markets are embedded (Anderson and Ruhs, 2010; Peck, 1996; Vosko, 2006). Prior literature shows that the deregularisation and informalisation of 'non-standard' employment relations for particular groups in the labour market, coupled with the parallel process of welfare state restructuring, have transformed the nature of employment relations in Europe making social-structural attributes such as age, gender and citizenship status key factors that differentiate the ability of workers with a certain level of education to attain formal, high quality, 'standard' employment. (Barbieri, 2009; Castels, 2015; cf. Kalleberg, 2011; Schierup et al., 2006). As these attributes intersect, young migrants may face multiple disadvantages in the labour markets.

To be sure, in today's Europe young people are generally far more likely than other groups to be employed in precarious jobs, to some extent regardless of their educational qualifications. As such, young workers are at risk of both being trapped in jobs that do not reflect their skills and qualifications while also suffering the impacts of non-standard and insecure employment arrangements - including internships and voluntary work - which have infiltrated professional industries and knowledge work. (Ross, 2008: 34; Samek Lodovici and Semenza, 2012.) In addition, while young workers frequently alternate between temporary jobs, unemployment and 'inactivity', in many countries they are disproportionately excluded from contributory social security schemes (Chung et al., 2012; Barbieri, 2009).

Moreover, migration scholars have identified a number of reasons why cross-border mobility may increase vulnerability to precarious employment. Especially among newly arrived migrants, language barriers, non-recognition of qualifications and limited knowledge of the labour market and employment rights in the receiving country can be significant (McKenzie and Forde, 
2009; Piore, 1979), while taking on temporary work can sometimes also be a migrant's 'strategic' choice to improve skills (Alberti, 2014). Besides, migrants' different frames of reference can make wages and working conditions in the receiving country seem acceptable or unacceptable when compared with the conditions back home (Piore, 1979; Waldinger and Lichter, 2003). These same considerations may also impact the extent to which migrants are able to make strategic use of crossborder mobility to reject or leave precarious jobs (Alberti, 2014). In addition, workers' nationality, along with their legal status, can be an important criterion that in the eyes of employers makes certain workers appear suitable for certain jobs and unsuitable for others (Anderson and Ruhs, 2010; cf. McDowell et al., 2009; McKenzie and Forde, 2009).

Furthermore, previous critical migration literature (e.g. Anderson, 2010; Calavita, 2005; De Genova, 2002; De Genova and Peutz, 2010; Goldring and Landolt, 2011) also establishes that states play a key role, with their immigration control and enforcement policies, in 'producing' temporariness, insecurity and 'illegality' of migrants' status and consequently in shaping their conditions in labour markets. However, the realities of EU citizens have been considered largely external to these debates (see Anderson, 2010; cf. Alberti, 2016). Although in principle EU citizens neither require work-permits nor are subject to immigration controls, this article nevertheless claims that the heightened efforts to restrict EU citizens' residence rights amount to boundary enforcement as they constitute barriers in their access to secure and enduring legal status. Consequently, precarious citizenship needs be considered as one explanatory variable for understanding the pressure on intra-EU migrants to accept precarious jobs, placing their experiences in the light of preceding scholarship that identifies as root causes for migrant workers' vulnerability the limitations of rights and protections associated with insecure citizenship statuses; temporariness and deportability (i.e. the threat of forced removal from the national territory); as well as dependence on employers for status and rights (Anderson, 2010; Calavita, 2005; De Genova and Peutz, 2010; Goldring, 2014; Lori, 2017; Menjívar, 2006; Munck et al., 2012). 


\section{Analysing precarious citizenship within the EU free movement regime}

Citizenship has become increasingly unsettled and precarious for many migrant and minority groups across the world with tremendous impact on their life-chances (Munck et al., 2012). Drawing on previous research addressing conditions of statelessness, 'illegality', temporary humanitarian protection and guest worker schemes, Lori (2017) analyses the global rise of boundary enforcement and, as its direct consequence, the proliferation of precarious citizenship that she defines as the structured uncertainty of being unable to gain access to secure legal status for protracted periods (2017: 743-751). Lori argues that states strengthen boundary enforcement, not only as a response to the growing backlash against migration, but also to avoid resolving larger dilemmas about citizenship, especially the questions about the formal incorporation of subnational populations (Lori, 2017: 746-751).

This article suggests that while citizenship is generally becoming less inclusive for nationals as well as for migrants (Somers, 2008), the research should not overlook the more 'privileged' types of migration when seeking to map the spread of precarious citizenship around the world. In particular, Lori underscores the way in which the denial, removal and delays in the issuance of adequate identity documents can critically impact migrants' lives and livelihood outcomes as they form the key to secure and permanent residency, protections and entitlements of the welfare state (also De Genova and Peutz, 2010: Lori, 2017: 743-753). This 'documentary lens' is also useful for exploring the growing status insecurities in the increasingly contested regime of EU free movement, where currently the mere possession of an EU passport does not guarantee access to secure and enduring legal status in another EU country. However, this approach needs to be complemented by greater attention paid to the role of institutional actors in enforcing conditionality and temporariness of migrants' ability to remain in a status, as proposed by Goldring 
(2014) in the Canadian context. Moreover, expanding Lori's discussion to a distinctively privileged migration regime requires moving the focus away from the persistence of precarious citizenship through time and towards analysing migrants' multidirectional movement across status categories, often contingent on their trajectories in the world of work (see Goldring and Landolt, 2011).

\section{The context for boundary enforcement under EU free movement legislation}

European Union level - vagueness of definitions and leeway for national interpretations

The European Commission in its official discourse and actions has for decades been forcefully promoting EU citizenship as a set of rights while seeking to encourage intra-EU mobility. Consequently, free movement has become the right that citizens themselves most closely associate with EU citizenship. (Favell, 2008: 16-17.) While intra-EU migrants are known to move with little knowledge of their rights (Ackers and Dwyer, 2002: 41), the discursive emphasis placed on the principle of equal treatment with nationals in other member states is prone to create expectations of rights and equality. However, freedom of movement has never been formally unconditional and the right to equal treatment is primarily reserved to those who fall within the category of 'worker'. According to the European Commission, "the term "worker" has a meaning in EU law and cannot be subject to national definitions or be interpreted restrictively':

It covers any person who undertakes genuine and effective work for which he is paid under the direction of someone else... Short duration of employment, limited working hours or low productivity cannot prevent an EU citizen from being considered an EU migrant worker... Part-time workers, trainees and au pairs fall within the EU definition if their activity is effective and genuine. (European Commission, 2010b.) 
Nonetheless, a number of factors have enabled certain EU countries to move towards a more restrictive understanding of EU citizens' rights without an explicit political decision at an EU level. Most importantly, the definitions of the concepts such as 'worker', 'jobseeker' and 'inactive person' continue to remain vague in EU law and significant leeway is left for national interpretations and bureaucratic discretion. The central aspect are the disparities in terms of temporariness of rights for people classified under these categories and the fact that their 'expiration-dates' are contingent on conditions and subject to discretion. For instance, 'jobseekers' residence is unqualified during the first six months. Following this period member states may require them to provide evidence that 'they are continuing to seek employment and that they have a genuine chance of being engaged' (European Commission, 2010b). The Free Movement Directive (2004/38) also leaves open the possibility for member states to expel an EU citizen who is considered to be putting an 'unreasonable burden' on its social assistance system.

While the transposition of EU law into national legislation is crucial here, ultimately the enforcement of both EU and national law takes place at the level of national administrations. The general and ambiguous nature of these categories and concepts would demand individual caseby-case assessments that in practice are difficult to handle by administrations engaged in mass procedures (Blauberger and Schmidt, 2017). At the same time, in many member states, more or less conscious circumvention of EU legislation takes place as they refuse to recognise nationals of other EU countries 'as co-citizens and holders of a right to equal treatment' (Kostakopoulou, 2014: 430). Also, the most recent rulings of the Court of Justice of the European Union have signalled a move away from its long-standing interpretation that EU citizenship is 'destined to become the fundamental status' and a move closer to a legal framework under which the right to residency and equal treatment are more closely interlinked (Alberti, 2016). 
In Belgium, the increasing popularity of nationalist and xenophobic parties has brought controlling migration, particularly from Central and Eastern European EU countries, into the political mainstream. The policies developed by the Belgian government as a response to this pressure are, in turn, increasing suspicion towards all intra-EU migrants. (Lafleur and Stanek, 2016: 112-114.) Restricting the migration of non-economically active foreigners has been a long-term political objective in the country but measures that specifically target EU citizens are a novelty that marks a major policy change (Gsir et al., 2016).

Belgium has sought to control EU citizens' access to its welfare system both by restricting the conditions of social entitlements for those legally residing in its territory and increasingly by restricting access to legal residence (cf. Shutes and Walker, 2018). At the same time, state efforts to establish administrative control over EU migrants' residency rights have significantly heightened. For instance, the practice of expelling EU citizens is based on data exchange between the social security administration and the Belgian immigration office, with considerable discretion in determining whether or not a person forms an 'unreasonable burden' (Meurens and Van Caeneghem, 2016: 15). Therefore, since 2010 an unparalleled number of EU citizens (3744 in 2014-2015) unable to provide evidence of paid work, 'a genuine chance of finding employment' or 'sufficient resources' have received an order to leave the territory ${ }^{2}$ (see Lafleur and Stanek, 2016).

From the perspective of migrants, the increasingly restrictive policies translate into bureaucratic struggles. This article therefore focuses on their interaction with the administrations the residency administration at the city halls in particular. The Brussels Capital Region is composed of 19 communes which, under the direction of the Federal immigration office, administer residence registration. The following analysis examines the role of these bureaucracies, not simply in 
implementing the laws and policies designed at a higher political level, but also in transforming them by using their discretion over EU citizens' status and rights. How do the administrative actors draw and enforce boundaries between different categories of employment status and work arrangements when determining EU citizens' access to residence rights? In what ways do these policies and administrative practices affect precarious EU citizens' ability to rely on and make claims for their rights? What kind of consequences do the temporary and insecure legal statuses have for young migrants' room for manoeuvre in the Belgian labour markets?

\section{Data and method}

The data consists of 27 in-depth narrative interviews with university-educated young adults (21-34 years old) from Italy (10), Spain (8), Finland (7) and Denmark (2) who had moved to Brussels to work but had subsequently experienced unemployment at some point during their stay. The gender distribution is balanced and their educational backgrounds represent a range of academic fields ${ }^{3}$, with degrees obtained on Master's or Doctoral level. For all the participants free movement had been a privilege taken for granted and most of them had taken part in national or EU mobility programmes, including Erasmus, Leonardo da Vinci and Erasmus for Young Entrepreneurs. For the vast majority of them, a wish to pursue an international or EU career was an important motivating factor to move to Brussels along with other factors such as a lack of job opportunities corresponding to their qualifications and poor working conditions in their countries of origin. While living in Brussels, they had all been engaged in different kinds of precarious work arrangements, such as series of short-term contracts and internships, false self-employment, temporary agency work, casual work and informal work.

The most important channels to recruit research participants were various Facebook groups formed around different nationalities living in Belgium/Brussels, together with projects and 
associations working to help their national group living in Belgium as well as the personal networks of the researcher. In addition, snowball sampling was used. The interviews took place in 2014 and 2015 in Brussels with the exception of two interviews, one of which was carried out in Finland and the other via Skype with an Italian who was doing voluntary work in Asia. The languages of the interviews were Spanish, Finnish or English. The Italians and Danes were interviewed in English. The participants have been given pseudonyms to ensure their anonymity.

The interviews were narratively-oriented (Cederberg, 2014) and in-depth, framed around work and mobility experiences. The résumés of the participants were used as interview material in order to help them recount their often complex and transnational employment trajectories in detail. Following a 'free narrative' section, in the second part of the interview the participants were asked questions concerning their experiences of working life and unemployment, their experiences with local bureaucracies, their awareness of their rights, problems faced in terms of recognition of their rights and their future plans and prospects. The interviews were analysed using qualitative content analysis (Mayring, 2000) concentrating on accounts of bureaucratic encounters. The participants' employment trajectories were reconstructed based on the interviews and the résumés. Subsequently, a systematic mapping of the complex contingencies between these trajectories and the evolution of participants' legal status and rights was conducted (cf. Goldring, 2014). The interviews contain numerous stories regarding barriers to social rights that the participants faced, in many cases despite having obtained a Belgian residence certificate. However, the following analysis will focus on the barriers in access to secure and enduring legal status in Belgium. 
Contrary to free movement legislation that refers to clear-cut categories of 'workers', 'jobseekers' and 'non-active citizens', the current labour market produces increasingly fragmented employment trajectories blurring the boundaries between work, 'job seeking' and inactivity as well as between formal and informal work arrangements (Munck et al., 2012). In Belgium's administrative practice these normative definitions have been translated into indeterminate and changeable requirements to demonstrate formal contracts of employment considered as adequate to render individuals eligible for the status of 'worker' and its associated rights. (See also Alberti, 2016.)

None of the participants were 'non-active' in the sense that, even when not employed, they were all engaged in paid or unpaid internships and other forms of unremunerated work and training, while actively, often feverishly, searching for paid employment. When the participants sought to register as residents in Brussels, these kinds of activities were in most cases not considered sufficient to trigger the right to be issued the national registration certificate with a national registry number. On occasion, front line officers insisted on a strictly temporary residence right of three months for job searching and only when the participants specifically asked did they align with the longer and more flexible period of 'at least six months' defined in EU legislation (European Commission, 2010b). Sometimes EU law was even openly disregarded by the officers who appeared to be more committed to delivering the national policy objective of protecting the domestic welfare system from 'outsiders' (cf. Heidlmaier and Blauberger, 2017). For example Jukka, from Finland, had lived most of his life in Belgium, graduated from a Belgian university and completed his $\mathrm{PhD}$ in France before returning to Belgium. Without employment or funding for his research, he was not considered eligible for unemployment benefit despite having an employment record in France. At the city hall he was told that he would be expelled if he could not find work within three months. 
And I said that, as far as I know, this is against EU legislation. And they said that yes but we have Belgian legislation not EU legislation... And I asked where do you want me to go since I've been registered in Belgium for 15 years and I'm not registered in Finland nor in France. So where am I supposed to go? And they told me that well, we don't care as long as you leave our country. And I asked if there was anything I could do and they said that you can apply for an extension... So they took away my ID card [registration certificate] and gave me a six-month extension to find a job.'

Jukka was not offered any justification for the expulsion other than his unemployment and, despite his qualifications and fluency in a local language, his chances of finding employment in Belgium were not considered 'genuine'. Lacking enduring and unambiguous legal status and the key identity document required in Belgium for most administrative and other transactions ${ }^{4}$, he continued to search for work under considerable pressure to find any job quickly that would reopen his access to legal residence and secure some level of subsistence.

While Jukka finally found temporary funding to continue his research work, other participants in a similar situation accepted any work they could find, often below their skill level, in order to be able to register as residents. Many southern Europeans especially judged that the labour market position of their national group had generally deteriorated during the years of economic crisis due to the influx of migrants from their respective countries into the city. In this context, the strict temporariness and uncertainty of their status further decreased their leeway for navigating the highly competitive job market and hampered their opportunities to be more ambitious with their job search. Therefore it often implied relinquishing their career aspirations, at least in the short term. For instance, Carlos had left his job in Spain and come to Brussels because his dream and vocation was to work in European affairs. However, as he urgently needed access to healthcare, he had accepted work as a school assistant to obtain a registration certificate: 
'They told me that "you have three months to look for a job"... and luckily in three months I did find the job that I have right now... I have a chronic illness and therefore I absolutely needed to have a doctor. And to have one you need to have a job. That's why the pressure... was a bit like a question of life and death... This is why the job I have does not give me anything as a worker, but as a citizen it has given me what I needed the most which was social security and an ID card [registration certificate].'

Furthermore, some interviewees were undertaking informal work based on which they could not claim the status of 'worker'. Christina, a Spaniard, decided to stay in Brussels after finishing her Erasmus year at a Belgian university as her professor had given her promises of future work opportunities that later turned out to be unpaid. Lacking financial resources, she was not able to accept his offer:

Christina: "So the only thing I found was a coffee shop... And I asked [the manager] for a contract because I needed it to be able to register at the municipality and she told me that during the winter she didn't have much work and that she couldn't....'

Author: 'And did you manage to register?'

Christina: 'When I finished my final project I went to the municipality. I didn't register and they told me that I could come back in 5-6 months. So after six months I went and I got my national registration number and from that moment on I could get registered at Actiris [employment office]... And now just when I received the attestation of my national registration number I was told, that I need to go back in October to find out whether they accept me as a resident here. I mean I don't understand how it works. I asked but I wasn't offered any information.'

Christina had undertaken waiting and childcare work and had also undertaken some professional projects, but in none of these relationships had the employer been willing to provide her with a formal employment contract. This way her legal status was effectively in the hands of her employers and her inability to draw upon any state protection in turn made her subsistence dependent on accepting further informal work. 
In sum, the use of employment contracts as the principal eligibility criteria has made intra-EU migrants' access to secure and enduring legal status in Belgium contingent on their contractual success (cf. Somers, 2008). Combined with the high competition for jobs, the prevalence of non-standard and/or unremunerated work and the refusal of employers to write formal employment contracts has effectively excluded precarious EU citizens from the sphere of rights reinforcing their dependency on employers both in terms of rights and livelihoods. (cf. Anderson, 2010: 311.)

Producing precarious citizenship through inexplicit policies and indeterminate administrative practices

As the experiences described above also indicate, the administrative actors competent for determining the residency rights of EU citizens have used their discretion in a highly randomised manner. The data shows that the requirements for EU citizens laid down at the residence registration have varied between the municipalities of Brussels and even between officers of the same office. Together with the changing laws and inexplicit policies, these indeterminate administrative practices have created a profound uncertainty of rights among EU migrants in nonstandard and insecure employment, thus adding to the insecurity and temporariness they already suffer due to their precarious employment situation.

The parallel stories of two participants illustrate how it has become virtually impossible to ascertain and understand one's rights in these indefinite settings. Coincidentally, Spaniards Alicia and Francisco had arrived in Belgium for internships of similar lengths for the same employer. However, while Alicia had no difficulties in obtaining a registration certificate with her internship contract, Francisco, who lived in a different municipality, was first required to 
register as a jobseeker and subsequently received an ambiguous letter leaving it unclear whether or not he was being ordered to leave Belgium.

Francisco: 'They let me register but as a jobseeker which means that even having my internship they said no. Not good enough... And it's also absurd that it depends on the officer. Because if one day I happened to deal with an officer who maybe treated me great and accepted everything and another day I was dealing with another one and that meant that I needed to prepare and bring twenty more papers proving that I was looking for work. I mean, it was something absurd, something, I don't know. Random.'

Author: 'And you received a letter [of expulsion]?'

Francisco: 'Yes, I received a letter but with a phrase crossed out: I mean I received a warning letter saying that the period I had for looking for employment had finished... and the last phrase 'you are ordered to leave the territory'. That was crossed out.'

In fact, ignoring the procedural safeguards set out in the Free Movement Directive (2004/38), the Belgian government has not offered information to the general public or to the persons directly affected regarding the grounds for the expulsions or the legal or economic consequences of an order to leave the territory (Marea Granate, 2015). Consequently, the general confusion around these practices had led to rumours circulating of other EU migrants' experiences and for some participants the threat of potential expulsion became a motivation for avoiding all contact with the authorities (cf. De Genova and Peutz, 2010). This was especially the case among Italians and Spaniards as these nationalities have been among the most affected by this practice (Lafleur and Stanek, 2016). Some of them defined their own status in Belgium as 'illegal' or 'clandestine' and while none was well enough informed to be sure what the actual consequences of an expulsion order would be, they had considered it safer not to register their presence or, if they nevertheless had started the registration process, not to claim social entitlements. Spaniard Alfredo offered a profound analysis of the social context the practice of expulsion had created: 
'So, all this has an impact on you. In reality you're afraid that this will happen to you so you don't ask for what you're entitled to. If you're entitled to it, I mean, I don't know because I never asked... How many rights we have can change every month depending on the laws they have. If you act thinking that you have the same rights as a Belgian you're going to have a bad scare... They have expelled 400 Spaniards. If you don't want to be one of these people you're not going to ask for anything... It's not [only] that we don't have rights but that we think [we have] rights that we don't really have and that you realise this now, when you're here.'

Italian Antonio, who had not found formal paid work despite an extensive job search, explained how he was struggling to get by with occasional freelance work while at the same time using his professional skills in voluntary work that he hoped would allow him one day to secure a job. However, he was running out of financial resources to continue this strategy. He had heard of other Italians who had received expulsion orders and was aware that this could possibly happen to him as well, if the Belgian authorities were to find out about his situation:

'I mean, I'm illegal here at the moment. I never registered... If you go to the commune without any kind of contract... from that moment they know you're here and they can look for you, they can tell you things. I'm not scared... [but] these are the moments when you say: maybe I should concentrate on looking for construction work or this kind of things seriously. It's difficult because I've no experience.'

All in all, it can be argued that the vagueness of the EU legal framework has enabled the Belgian government to adopt insidious policies towards intra-EU migrants with pitfalls leading to loss of residency rights (see also Mescoli and Lafleur, 2016). The possible consequences of government policies and administrative practices are touched upon in the interview with Italian Luca, who had not registered his residency and was working as a deliveryman despite his two university degrees. He commented how employers in certain sectors were taking advantage of the growing supply of EU citizens living under vulnerable conditions: 'The food sector, for instance, 
it's full of people like me without contracts. Black market conditions. Italians as well as Spaniards... I mean European citizens working under the same bad conditions as the 'sans papiers' [undocumented migrants]'.

Compared with undocumented non-EU migrants, as EU citizens their options remained more extensive given that they could regularise their legal status if they found formal, paid work and their 'time horizon' could hence expand (cf. Anderson, 2010: 306). However, it could also potentially compress if their legal status evolved in the opposite direction in the event of termination of their contracts (cf. Mescoli and Lafleur, 2016). Another route for regularisation, also owing to the pressures of a difficult labour market and widespread subcontracting, was through registering as a self-employed worker, though this often provided only limited means of subsistence and access to social security. Additionally, as residence rights could also be derived from officially recognised relationships with a Belgian national or another EU citizen classified as a 'worker', some participants had - often somewhat reluctantly - formalised their relationships and hence placed themselves under the 'charge' of their partners.

As EU citizens, the participants were also free to continue their journey to yet another member state, but many had not used this possibility to escape their precarious situation as they had not given up their ambitions of eventually starting an international career and/or they had established personal ties in Brussels (cf. Alberti, 2014, 2016). Moreover, as Lori (2017: 752) notes, financial and social capital may mitigate the extent to which uncertain citizenship status leads to economic insecurity and in this respect there were considerable disparities between the participants. Most importantly, for many of the Nordics, the option of returning to their countries of origin still existed as a considerable back-up plan in case the conditions they faced in Belgium became overly harsh, and sometimes they also were able to benefit from their domestic welfare systems while living in Belgium. In contrast, many southern Europeans had no social benefits to export from their 
home countries and stayed as they did not expect their conditions to be any easier back home or anywhere else in Europe.

\section{Conclusions}

Making use of mobility rights is increasingly risky for intra-EU migrants who, by moving to another member state, expose themselves - often unknowingly - to the constantly evolving national and supranational legal frameworks and the changeable boundaries within the status of 'EU citizen'. The ever more restrictive interpretation of EU citizens' rights resonates with a more general shift within Western welfare states towards policies that emphasise an individual's obligation to participate in paid employment as a condition for 'earning' their rights and protection (Somers, 2008). The concomitant decline in the prevalence of 'standard' employment relationships creates new forms of institutionally originated social inequality wherever social rights are stratified and tied to uninterrupted work careers (Barbieri, 2009; Vosko, 2006).

This article expands Noora Lori's (2017) discussion on precarious citizenship by claiming that, under the conditions of precarious employment, not even intra-EU migrants with privileged access to formal citizenship rights are protected from processes of boundary enforcement resulting in insecure and temporary statuses. It focuses on the experiences of young intra-EU migrants who, despite their qualifications, had faced multiple forms of disadvantage in the world of work and therefore became vulnerable to precarious citizenship. At the same time, other groups of EU citizens exposed to diverse forms of informal and precarious work are likely to meet similar obstacles (Shutes and Walker, 2018). A potential for precarious citizenship is hence emerging in the context of EU free movement, although for intra-EU migrants it is not likely to become as persistent and definitive a state as for many other migrant and stateless people around the globe (see Lori 2017; 747-748). 
The law and its institutional enforcement often combine contradictory economic policy rationalities and calculations with other logics that are more socio-political (e.g. contestation over migration, foreign relations) and ethno-cultural (e.g. xenophobia) in nature (De Genova, 2002: 425; Lori, 2017: 750-751; Paul, 2015: 34-45). Following Lori's (2017: 744) argument, the policies and practices that produce precarious citizenship for intra-EU migrants can be interpreted as a strategic response of member states' governments to avoid resolving the conflicting dilemma of EU citizenship, with increasing popular and political pressure to establish control over intra-EU migration on the one hand and the binding EU rules requiring equal treatment of EU workers on the other (cf. Schierup et al., 2006). From the perspective of individual EU citizens affected, these policies and practices thwart expectations of rights and equality and curtail their room for manoeuvre in the highly competitive labour market.

The fact that EU member states have given up much of their sovereign power to regulate intra-EU migration has hidden the responses to the political pressure to control it, responses which disregard the limitations set by EU rules (Lillie and Simola, 2016). Exploring the emergence of precarious citizenship within the EU free movement regime through the lens of Brussels, this article argues that, in the absence of straightforward EU legislation and explicit government policies at a national level, administrative actors are using their discretion over EU citizens' rights in a highly randomised manner making it exceedingly difficult for intra-EU migrants to rely on rights. While the expulsion threats and orders may only be flawed 'instruments of state sovereignty' and, thus far, EU citizens have not been effectively 'deportable' in Belgium (cf. De Genova and Peutz, 2010: 6; see also Mescoli and Lafleur, 2016), the analysis shows how the stateenforced uncertainty of status and rights has effects that deceptively resemble the 'administrative death' that has been the real consequence of actual expulsions (see Meurens and Van Caeneghem, 2016). These policies and practices are therefore prone to have an impact on a much wider population than the people the expulsions directly affect. Their perhaps unintentional but inevitable 
outcome is the emergence of a growing group of EU citizens living and working in the country under temporal and insecure status or devoid of any legal status. Therefore they are also likely to increase the supply of EU migrant workers ready to work under precarious conditions (cf. Alberti, 2016; cf. Anderson, 2010). These findings highlight the need for more comprehensive research that does not overlook the presumed 'privileged' types of migration to further develop the theoretical understanding on precariousness in its embeddedness in institutional processes and micro-level interactions.

\section{Acknowledgements}

For highly valuable comments, many thanks to Camilla Nordberg, Sirpa Wrede, Gabriella Alberti, Jean-Michel Lafleur, Nathan Lillie as well as the editor and all anonymous referees. I would like to give a special thanks to Sirpa Wrede for introducing me to the work of Noora Lori and for suggesting the concept of 'precarious citizenship' to be applied in this article.

\section{Funding}

This research receives funding from Palkansaajasäätiö, Centre of Excellence for Research on Ageing and Care (RG 3 Migration, Care and Ageing, \#312310) and from Academy of Finland project 'Citizenisation in the Local Welfare State' (no. 1273392).

\section{Notes}

1. The interview extracts in Finnish and Spanish have been translated into English.

2. This practice clearly infringes the Free Movement Directive (2004/38) which lists numerous safeguards, inter alia, prohibiting systematic expulsions as well as expulsions as an automatic consequence of applying for social assistance (European Commission, 2013). 
3. International or EU law/economics/business; journalism and audio-visual media; social/political/humanist sciences, architecture, languages/interpretation, biology, HR management, tele-engineering.

4. The registration certificate with a national registry number is generally required in Belgium for opening bank accounts, signing rental contracts, signing employment contracts with public bodies, joining mutual health insurance funds and accessing public services, as well as further administrative processes.

\section{References}

Ackers L and Dwyer P (2002) Senior Citizenship? Retirement, migration and welfare in the European Union. Bristol: Polity Press.

Alberti G (2014) Mobility strategies, 'mobility differentials' and 'transnational exit': the experiences of precarious migrants in London's hospitality jobs. Work, employment and society 28(6): 1-17.

Alberti G (2016) A new status for migrant workers: restrictions of the free movement of labour in the EU. Mondi Migranti 3: 33-49. 
Anderson B (2010) Migration, immigration controls and the fashioning of precarious workers. Work, employment and society 24(2): 300-317.

Anderson B (2015) Immigration and the Worker Citizen. In: Anderson B and Hughes V (eds) Citizenship and Its Others. Basingstoke: Palgrave, 41-57.

Anderson B and Ruhs M (2010) Migrant Workers: Who Need Them? A Framework for the Analysis of Staff Shortages, Immigration, and Public Policy. In: Ruhs M and Anderson B (eds) Who Needs Migrant Workers? Labour Shortages, Immigration, and Public Policy. Oxford: Oxford University Press, 15-52.

Barbieri P (2009) Flexible Employment and Inequality in Europe. European Sociological Review 25(6): 621-628.

Blauberger M and Schmidt SK (2017) Free movement, the welfare state, and the European Union's over-constitutionalization: Administrating contradictions. Public Administration 95(2), 437-449.

Calavita, K (2005) Immigration at the Margins: Law, Race and Exclusion in Southern Europe. Cambridge: Cambridge University Press. 
Castles S (2015) Migration, Precarious work and Rights. Historical and Current Perspectives. In: Schierup U, Munck R, Likíc-Brboric B and Neergaard A (eds) Migration, Precarity and Global Governance. Challenges and Opportunities for Labour. Oxford: Oxford University Press, 46-67.

Cederberg M (2014) Public Discourses and Migrant Stories of Integration and Inequality: Language and Power in Biographical Narratives. Sociology 48(1): 133-149.

Chung H, Bekker S and Houwing H (2012) Young people and the post-recession labour market in the context of Europe 2020. Transfer: European Review of Labour and Research 18(301): 301-317.

De Genova N (2002) Migrant 'Illegality' and Deportability in Everyday Life. Annual Review of Anthropology 31: 419-447.

De Genova N and Peutz N (eds) (2010) The Deportation Regime: Sovereignty, Space, and the Freedom of Movement. Durham: Duke University Press.

EURES (2016) Labour market information, Belgium - Région De Bruxelles-Capitale. Available at: https://ec.europa.eu/eures/main.jsp?lang=en\&acro=lmi\&catId=7552\&countryId=BE\&regionId=BE 1 
European Commission (2010a) Youth on the Move. An initiative to unleash the potential of young people to achieve smart, sustainable and inclusive growth in the European Union. Brussels: European Commission.

European Commission (2010b) Communication from the Commission: Reaffirming the free movement of workers: rights and major developments. Available at: http://eur-lex.europa.eu/legalcontent/EN/TXT/?uri=celex\%3A52010DC0373

European Commission (2013) February infringements package: main decisions: Free movement: Commission asks Belgium to comply with EU rules. Available at: http://europa.eu/rapid/pressrelease_MEMO-13-122_en.htm

Favell A (2008) Eurostars and Eurocities: Free Movement and Mobility in an Integrating Europe. London: Blackwell.

Goldring L (2014) Resituating Temporariness as the Precarity and Conditionality of Noncitizenship. In: Latham, R Vosko L and Preston-Dunlop V (eds) Liberating Temporariness?: Migration, Work, and Citizenship in an Age of Insecurity. Montréal: MQUP. 
Goldring L and Landolt P (2011) Caught in the Work-Citizenship Matrix: the Lasting Effects of Precarious Legal Status on Work for Toronto Immigrants. Globalizations 8(3): 325-341.

Gsir S, Lafleur JM and Stanek M (2016) Migration policy reforms in the context of economic and political crises: the case of Belgium. Journal of Ethnic and Migration Studies 42(10): 1651-1669.

Heindlmaier A and Blauberger M (2017) Enter at your own risk: free movement of EU citizens in practice. West European Politics 40(6): 1198-1217.

Kalleberg AL (2011) Good Jobs, Bad Jobs. The Rise of Polarized and Precarious Employment Systems in the United States, 1970s-2000s. New York: Russell Sage Foundation.

Kostakopoulou D (2014) European Union citizenship rights and duties. Civil, political and social. In: Isin EF and Nyers P (eds) Routledge Handbook of Global Citizenship Studies. New York: Routledge, 427-436.

Lafleur JM and Stanek M (2016) Restrictions on Access to Social Protection by New Southern European Migrants in Belgium. In: Lafleur JM and Stanek M (eds) South-North Migration of EU Citizens in Times of Crisis. Basel: Springer, 99-121. 
Lillie N and Simola A (2016) The Crisis of Free Movement in the European Union. Mondi Migranti 3: 7-19.

Lori, NA (2017) Statelessness, 'In-Between' Statuses, and Precarious Citizenship. In: Shachar A, Bauböck R, Bloemraad I and Vink M (eds) The Oxford Handbook of Citizenship. Oxford: Oxford University Press: 743-766.

Marea Granate (2015) Official complaint to the committee of petitions of the European Parliament. Available at: http://mareagranate.org/wp-content/uploads/2014/05/Peticion-sobre-expulsionesdirectiva-200438.pdf

Mackenzie R and Forde C (2009) The Rhetoric of the "Good Worker" versus the Realities of Employers' Use and the Experiences of Migrant Workers'. Work, Employment and Society 23(1): $142-159$.

Mayring P (2000) Qualitative Content Analysis. Forum: Qualitative Social Research 1(2).

McDowell L, Batnitzky A and Dyer S (2009) Precarious work and economic migration: emerging immigrant divisions of labour in Greater London's service sector. International Journal of Urban and Regional research 33(1): 3-25. 
Menjívar C (2006) Liminal Legality: Salvadoran and Guatemalan Immigrants' Lives in the United States. American Journal of Sociology 111(4): 999-1037.

Mescoli E and Lafleur JM (2016) Welfare and the Creation of Undocumented Migrants in Belgium. Paper presented at IMISCOE Annual Conference on 1 July 2016. Available at: http://orbi.ulg.ac.be/handle/2268/192286

Meurens N and Van Caeneghem J (2016) Obstacles to the right of free movement and residence for EU citizens and their families: Country report for Belgium. Brussels: European Parliament.

Munck R, Schierup CU and Delgado Wise R (2012) Migration, Work and Citizenship in the New World Order. In: Munck R, Schierup CU and Delgado Wise R (eds) Migration, Work and Citizenship in the New Global Order. Oxon: Routledge, 1-12.

O'Brien C (2016) 'Civis capitalist sum: Class as the new guiding principle of EU free movement rights'. Common Market Law Review 53(4): 937-977. 
O’Reilly J, Froud J, Sukhdev J, Williams K, Warhurst C, Morgan G, et al. (2016) Brexit: understanding the socio-economic origins and consequences. Socio-Economic Review 14(4): 807854.

Paul R (2015) The Political Economy of Border Drawing: Arranging Legality in European Labour Migration Policies. New York: Berghahn.

Peck, J (1996) Work-place. The Social Regulation of Labour Markets. New York: Guilford Press.

Piore, MJ (1979) Birds of Passage: Migrant Labour and Industrial Societies. Cambridge: Cambridge University Press.

Rodgers G (1989) Precarious work in Western Europe: The state of the debate. In: Rodgers G and Rodgers JJ (eds) Precarious Jobs in Labor Market Regulation: The Growth of Atypical Employment in Western Europe 1. Geneva: ILO, 1-16.

Ross A (2008) The New Geography of Work: Power to the Precarious? Theory, Culture and Society 25(7-8): 31-49. 
Samek Lodovici M and Semenza R (2012) Precarious work and high-skilled youth in Europe. In: Samek Lodovici M and Semenza R (eds) (2012) Precarious work and high-skilled youth in Europe. Milan: FrancoAngeli, 11-23.

Schierup CU, Hansen P and Castels S (2006) Migration, Citizenship, and the European Welfare State. A European Dilemma. Oxford: Oxford University Press.

Shutes I (2016) Work-related conditionality and the access to social benefits of national citizens, EU and non-EU citizens. Journal of Social Policy 45(4): 691-707.

Shutes I and Walker S (2018) Gender and free movement: EU migrant women's access to residence and social rights in the U.K.. Journal of Ethnic and Migration Studies 44(1): 137-153.

Somers MR (2008) Genealogies of Citizenship. Markets, Statelessness, and the Rights to Have Rights. Cambridge: Cambridge University Press.

Vosko LF (2006) Precarious Employment: Towards an Improved Understanding of Labour Market Insecurity. In: Vosko LF (ed) Precarious employment: Understanding labour market insecurity in Canada. Montréal: MQUP: 3-40. 
Waldinger, RD and Lichter, M (2003) How the Other Half Works: Immigration and the Social Organization of Labor. Berkeley: University of California Press. 